\title{
Chromoblastomycosis Caused by Fonsecaea pedrosoi
}

\author{
Dong Min Kim, M.D., Sung Min Hwang, M.D., Moo Kyu Suh, M.D., Gyoung Yim Ha, M.D. , \\ Gwang Seong Choi, M.D. ${ }^{2}$, Jeonghyun Shin, M.D. ${ }^{2}$, Sung Hyub Han, M.D. ${ }^{2}$ \\ Departments of Dermatology and ${ }^{1}$ Laboratory Medicine, College of Medicine, Dongguk University, Gyeongju, ${ }^{2}$ Department of \\ Dermatology, College of Medicine, Inha University, Incheon, Korea
}

\begin{abstract}
We report herein a case of chromoblastomycosis caused by Fonsecaea ( $F$.) pedrosoi in a 39-year-old male, who showed multiple, asymptomatic, scaly erythematous plaques on the left shin for 12 months. Histopathologically, chronic granulomatous inflammation and either sclerotic or muriform cells were observed. The fungal culture produced typical black colonies of $F$. pedrosoi. The DNA sequence of the internal transcribed spacer (ITS) region of the clinical sample was $100 \%$ match to that of $F$. pedrosoi IFM 47061 (GenBank accession number AB240943). The patient was treated with $200 \mathrm{mg}$ of itraconazole daily, for 3 months. Skin lesions were improved. In Korea, only 9 cases of chromoblastomycosis, including this case, have been reported until now. The etiologic agent was $F$. pedrosoi in the majority of cases $(6 / 9 ; 67 \%)$. The incidence of chromoblastomycosis was slightly higher in female, and the upper limbs were more affected than the lower limbs in patients. (Ann Dermatol 23(3) $369 \sim 374,2011$ )
\end{abstract}

\section{-Keywords-}

Chromoblastomycosis, Fonsecaea pedrosoi

\section{INTRODUCTION}

Chromoblastomycosis is a chronic disease caused by

Received June 8, 2010, Revised July 15, 2010, Accepted for publication July 15, 2010

Corresponding author: Moo Kyu Suh, M.D., Department of Dermatology, Gyeongju Hospital, College of Medicine, Dongguk University, Seokjang-dong, Gyeongju 780-350, Korea. Tel: 82-54-7708268, Fax: 82-54-773-1581, E-mail: smg@dongguk.ac.kr

This is an Open Access article distributed under the terms of the Creative Commons Attribution Non-Commercial License (http:// creativecommons.org/licenses/by-nc/3.0) which permits unrestricted non-commercial use, distribution, and reproduction in any medium, provided the original work is properly cited. saprophagous dematiaceous fungi, when it enters through an open wound and infects both skin and subcutaneous tissue. This disease is mostly reported in tropical and subtropical areas and is often caused by Fonsecaea ( $F$.) pedrosoi. Other lesser etiologic agents are Cladosporium (Cladophialophora) carrionii, Phialophora verrucosa, Rhinocladiella aquaspersa, F. compacta, Exophiala (E.) dermatitidis, E. jeanselmei and E. spinifera ${ }^{1-5}$.

This rare skin disease, caused by fungus profundus, is rarely reported in Korea, compared to Japan ${ }^{4-7}$, even though these two countries are in the same Northeast Asia region. In Korea, clinical and histological findings have led to diagnosis of this disease by Ahn and Lee ${ }^{8}$ in 1990. Since the first identification of the etiologic agent by Suh et al. ${ }^{9}$ in 1996 , only 8 cases have been reported ${ }^{8-15}$.

Therefore, we present herein the case of a 39-year-old male patient who developed multiple erythematous plaques on the left lower leg. Clinical and histopathological findings, as well as fungus culture, light microscope findings and molecular biological analysis, have led us to diagnose the patient with chromoblastomycosis, caused by F. pedrosoi. The findings were presented with a review of the literature and previous reports of chromoblastomycosis in Korea.

\section{CASE REPORT}

A 39-year-old male presented with scaly erythematous plaque, with ulceration on the left shin (Fig. 1 and 2). He was a Thai worker living in Korea, and without specific traumatic event, he had the asymptomatic eythematous papule for 12 months. The patient had history of visiting Thailand 15 months ago. The lesion gradually increased in size and eventually developed into ulcerative erythematous plaque. His past medical history and family history was unremarkable. On physical examination, the general physical condition was good and there were no specific 


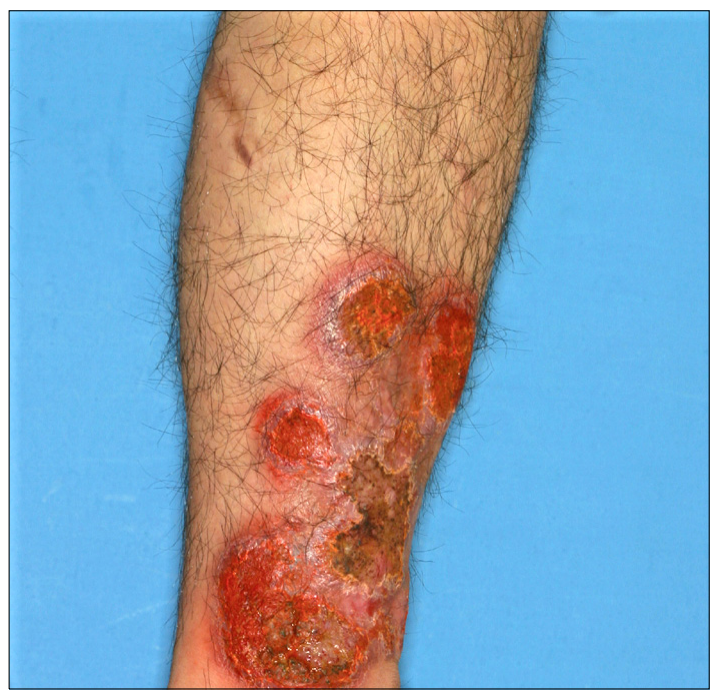

Fig. 1. Multiple, scaly erythematous plaques, with ulcers and erosions on the left shin.

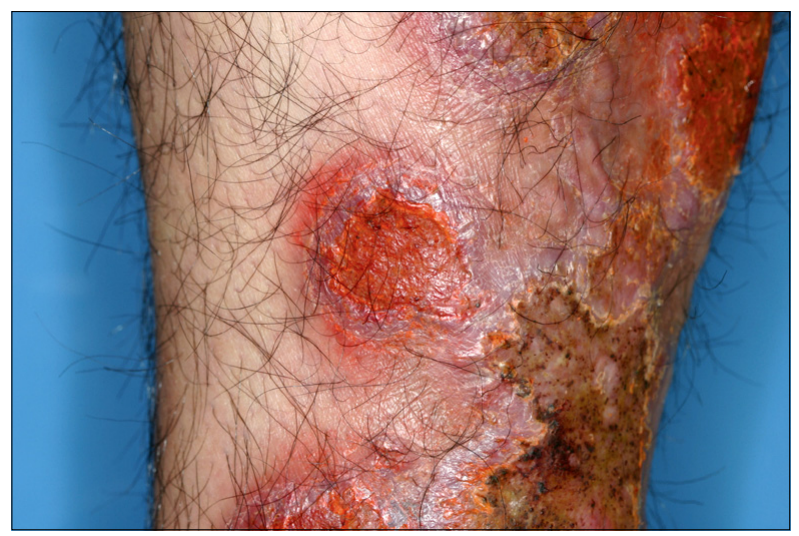

Fig. 2. Close-up view of the left shin.

findings, except for the skin lesion. On the visit, laboratory studies, including complete blood cell count with differentials, peripheral blood smear, liver and renal function test, VDRL, urinalysis, stool examination, hepatitis viral test, HIV test, chest X-ray, and electrocardiogram were all within normal limits or negative. $\mathrm{KOH}$ mount did not result in finding of any etiological agent. However, tissue biopsy conducted by culturing the tissue in the Sabouraud's dextrose slant medium showed slow growing, velvet-like, dark brown colonies, with slightly elevated center. Same result was found with subculture on plate medium (Fig. 3 and 4). According to microscopic examination with Lactophenol cotton blue staining for hyphae and conidia, conidiophores were brown, and ovoid conidia were located either at end or at the side of conidiophores (Fig. 5). Histopathological examination revealed chronic granulo-

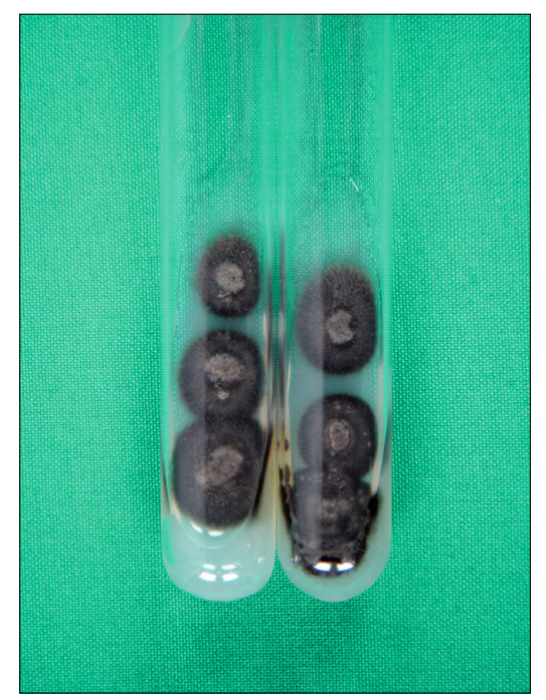

Fig. 3. Slow growing, dark brown, velvety colonies on the Sabouraud's dextrose agar slants cultured for 2 weeks, at $25^{\circ} \mathrm{C}$.

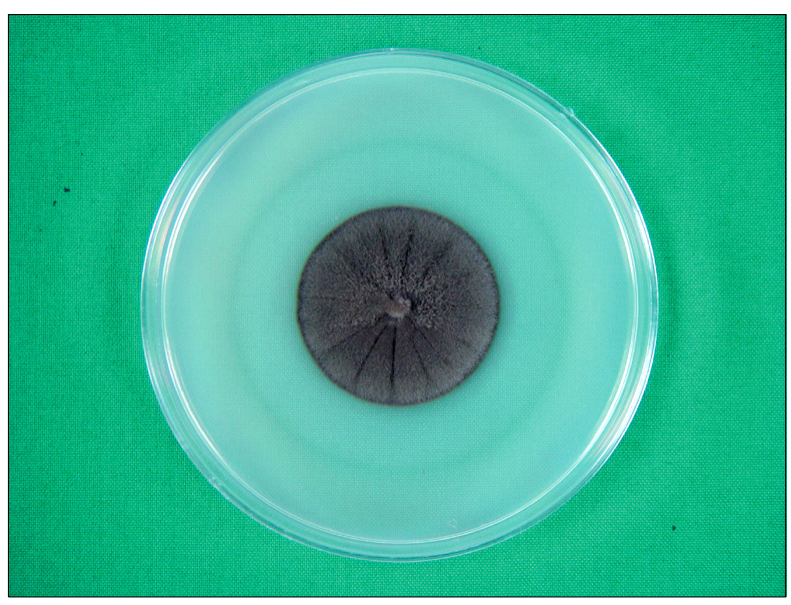

Fig. 4. Slow growing, dark brown, mildly heaped, velvety colony on the Sabouraud's dextrose agar cultured for 4 weeks, at $25^{\circ} \mathrm{C}$.

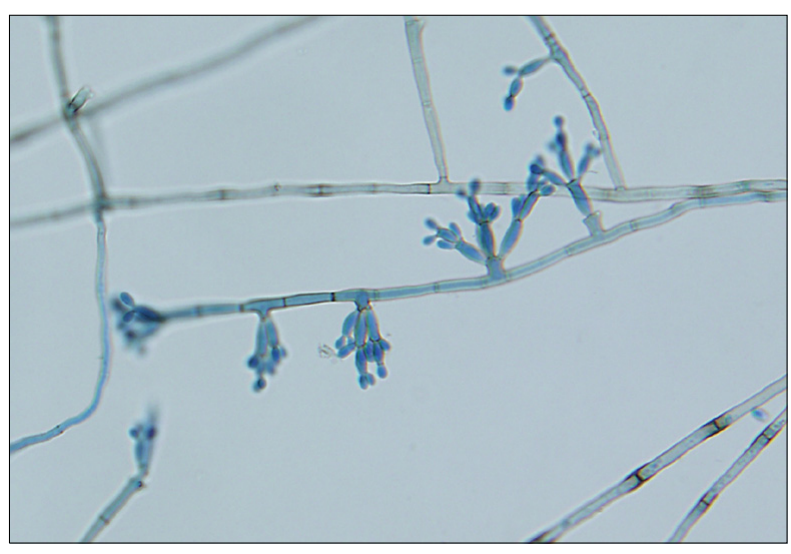

Fig. 5. Elliptical, brownish conidia from conidophore were seen in the slide culture of $F$. pedrosoi (Lactophenol-cotton blue stain, $\times 400)$. 
matous inflammation, with phase disseminated hyperplastic, minute abscess and intradermal lymphocytes, histiocytes, and giant cells (Fig. 6). Also, large spherical thick walled cells formed a cluster (Fig. 7). For Molecular biological analysis, DNA was extracted from the cultured colonies and the base sequence of ITS was identified. Subsequently, using the Blast program, it was compared to the base sequence of the reported strain in Thailand (stored in GeneBank), i.e. F. pedrosoi IFM 47061 (GenBank accession number AB240943). The result was a $100 \%$ match (Fig. 8). With clinical, histopathological and mycological results, as well as molecular biological findings, we were able to diagnose the patient as having chromoblastomycosis caused by the strain F. pedrosoi. The patient showed clinical improvement to 3 months

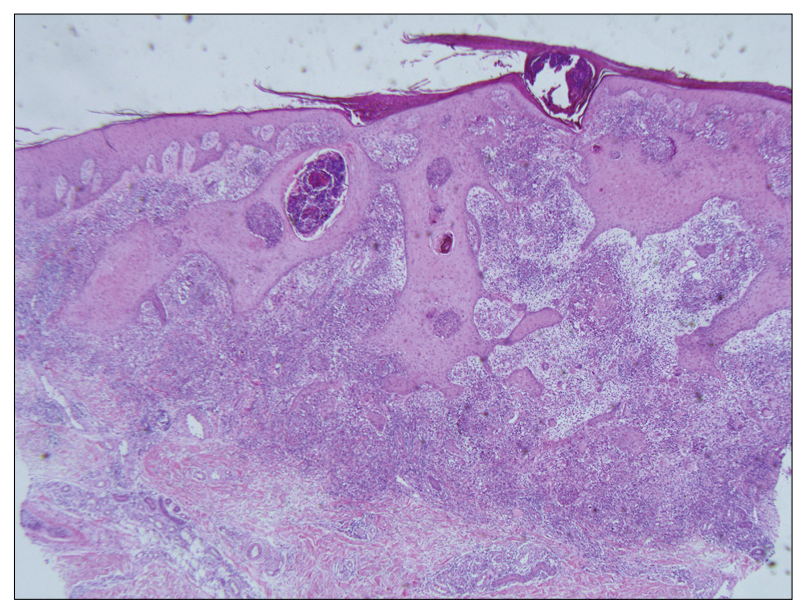

Fig. 6. The biopsy specimen showed pseudoepitheliomatous hyperplasia and chronic granulomatous inflammation $(\mathrm{H} \& \mathrm{E}$, $\times 40)$. oral administration of itraconazole, 200 mg per day.

\section{DISCUSSION}

Chromoblastomycosis is a chronic fungal disease mostly localized in the skin and the subcutaneous tissue. The disease is caused by dematiaceous fungi, with commonality of the melanin pigment containing cell wall. The infection is through open wound on the skin. Although there were some reported cases of animal infection, most infections occur in human subjects ${ }^{16}$.

This disease is reported in all continents. However, humid tropical and subtropical regions of America, Asia and Africa had more frequently reported the incidents ${ }^{1,2}$ and the etiologic agent was most often F. pedrosoi. Other

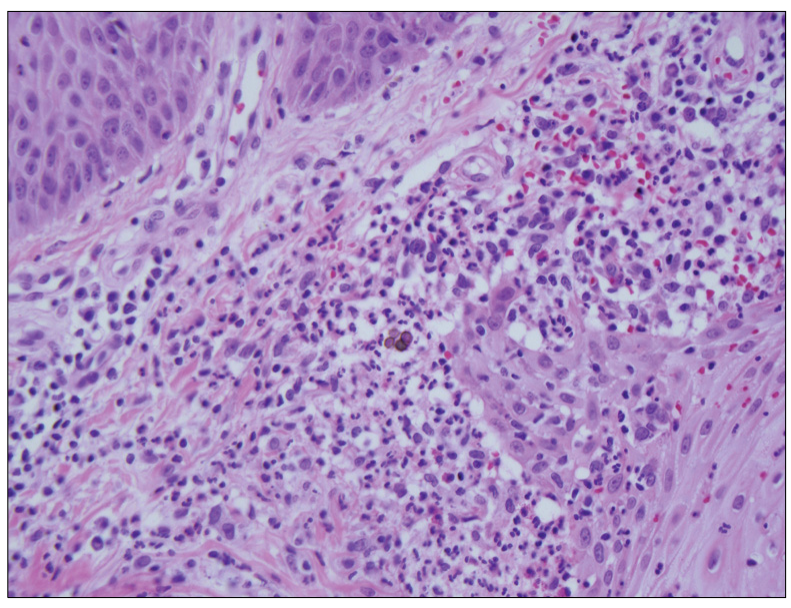

Fig. 7. Large, dark brown, septate cells, i.e, "sclerotic or muriform cells", in the upper dermis $(H \& E, \times 400)$.

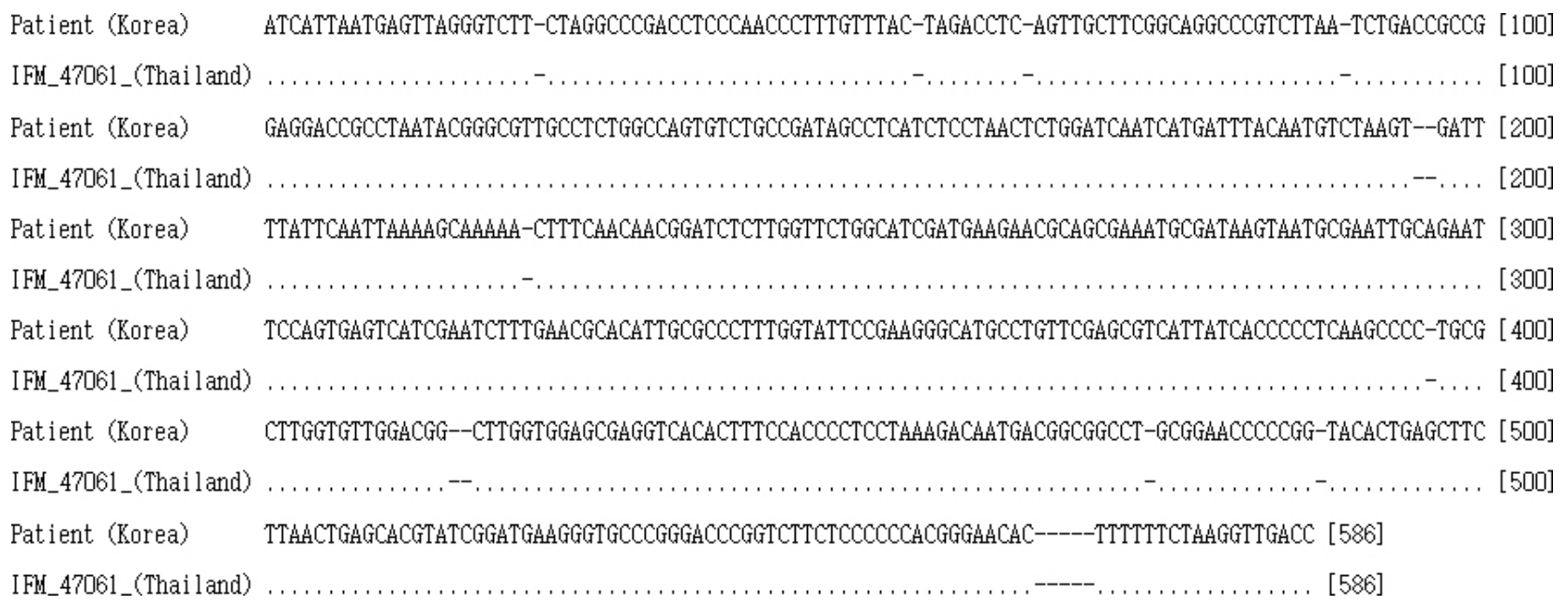

Fig. 8. Alignment of ITS sequences of the sample from the patient and F. pedrosoi IFM47061 (GenBank accession number AB240943). The sequences of ITS of the clinical samples were 100\% match to that of $F$. pedrosoi IFM 47061 (GenBank accession number AB240943). ITS: internal transcribed spacer. 
etiologic agents are Cladosporium (Cladophialaphora) carrionii, Phialophora verrucosa, Rhinocladiella aquaspersa, F. compacta, Exophiala (E.) dermatitidis, E. jeanselmei and $E$. spinifera ${ }^{1-5}$. The most reported agent responsible for incidents in Korea $\left(5\right.$ cases $^{9-13}$ ), also was $F$. pedrosoi, followed by Rhinocladiella aquaspersa ${ }^{14}$ and Phialophora verrucosa ${ }^{15}$ (1 case each).

The disease generally occurs more frequently in males then females and all ages can be affected. However, ages between $30 \sim 50$ and male farmers were most likely to develop the disease ${ }^{1-3,5}$. The age and sex distribution can differ depending on the region. In reported cases in South America $^{17,18}$, most cases were males of 30 50 years of age. In Japan, however, the incidence of male and female was similar and people over 50 were most affected by the disease $^{6}$. In Korea, the ratio of incidents in regards to sex was similar to Japan, in that 4 cases were male and 5 cases were female (this case included). With regard to age, 7 out of 9 cases occurred in the age group over 50 , which is also similar to the trend in Japan, rather than South America (Table 1$)^{8-15}$. This disease generally manifest itself on the lower extremity rather than the upper extremity, and the skin rash mostly starts off as red papule and gradually takes various forms, such as verrucous nodule or plaque $^{5}$. In Korea, however, the infection occurred more often on the upper extremity rather than the lower extremity. The low extremity was infected more in males, whereas the upper extremity was more infected in females. Clinical manifestations were mostly erythematous plaque type or nodular plaque type. This is also similar to the case reports from Japan, rather than from South America $^{17,18}$. Therefore, it seems to be a correlation between the geographical region and the incidents. This regional discrepancy might derive from differences in the level of industrialization and life style.

Histopathologically, chronic granulomatous inflammation, with phase disseminated hyperplastic, minute abscess and intradermal inflammatory cells were identified. Also characteristic, when the massive intradermal cell or separation by large spherical thick wall (sclerotic or muriform cell) can be seen, then it can be diagnosed as Chromoblastomycosis. The sclerotic or muriform cell can be observed easily, even in non-stained samples ${ }^{9,19}$. In this case, the same results were observed.

Mycological opinion was formed from the following findings. $\mathrm{KOH}$ mount showed the sclerotic cells and tissue biopsy conducted by culturing the tissue for a few days in the Sabouraud's dextrose medium, at $25^{\circ} \mathrm{C}$, showed development of the dark brown colonies. The microscopic examination resulted in identification of 3 types of sporulation. First, was the Cladosporium type, where conidium is formed, leading to chains. Second, was the Rhinocladiella type, where spore is formed at either the end or the side of the conidophore. Third, was the Phialophora type, where spore is formed at the end of the flask type conidophore, named Phialide $^{2}$. In this case study, the $\mathrm{KOH}$ mount did not result in finding of any etiologic agent. However, the tissue biopsy conducted by culturing the tissue in the Sabouraud's dextrose medium showed slow growing, velvet-like, dark brown colonies,

Table 1. Clinical features in the Korean cases of subcutaneous chromoblastomycosis

\begin{tabular}{|c|c|c|c|c|c|c|c|}
\hline $\begin{array}{l}\text { Author } \\
\text { (Year) }\end{array}$ & Sex/Age & Duration & Site & Skin lesion & Symptom & Causative organism & Tx \\
\hline $\begin{array}{l}\text { Ahn and Lee }{ }^{8} \\
(1990)\end{array}$ & M/55 & 1 year & Lower leg & Verrucous plaque & Pruritic & · & $\begin{array}{r}\text { Excision \& } \\
\text { AMP-B iv }\end{array}$ \\
\hline $\begin{array}{l}\text { Suh et al. }{ }^{9} \\
(1996)\end{array}$ & $\mathrm{F} / 58$ & 7 months & Wrist & Erythematous plaque & $\begin{array}{l}\text { Mild } \\
\text { pruritic }\end{array}$ & Fonsecaea pedrosoi & $\begin{array}{l}\text { AMP-B } \\
\text { il inj }\end{array}$ \\
\hline $\begin{array}{l}\text { Kim et al. }{ }^{10} \\
(1997)\end{array}$ & $M / 68$ & 5 years & $\begin{array}{l}\text { Dorsum of } \\
\text { hand }\end{array}$ & Verrucous plaque & $\begin{array}{l}\text { Asymp- } \\
\text { tomatic }\end{array}$ & Fonsecaea pedrosoi & ICZ \\
\hline $\begin{array}{l}\text { Kim et al. } \\
(2000)\end{array}$ & $\mathrm{F} / 65$ & 2 years & Forearm & Verrucous plaque & $\cdot$ & Fonsecaea pedrosoi & $\begin{array}{l}\text { AMP-B } \\
\text { cream }\end{array}$ \\
\hline $\begin{array}{l}\text { Kang et al. }{ }^{12} \\
(2002)\end{array}$ & $\mathrm{F} / 56$ & 2 years & $\begin{array}{l}\text { Dorsum of } \\
\text { hands }\end{array}$ & Deep ulcer & $\cdot$ & Fonsecaea pedrosoi & $\begin{array}{l}\text { Excision \& } \\
\text { grafting }\end{array}$ \\
\hline $\begin{array}{l}\text { Lee et al. }{ }^{13} \\
(2003)\end{array}$ & $M / 54$ & 4 years & Thigh & Erythematous plaque & Pruritic & Fonsecaea pedrosoi & TBF \\
\hline $\begin{array}{l}\text { Jun et al. }{ }^{14} \\
(2004)\end{array}$ & $\mathrm{F} / 52$ & 6 months & Abdomen & Verrucous plaque & . & Rhinocladiella aquaspersa & $\begin{array}{l}\text { ICZ \& } \\
\text { excision }\end{array}$ \\
\hline $\begin{array}{l}\text { Park et al. }{ }^{15} \\
(2005)\end{array}$ & $\mathrm{F} / 37$ & . & Chest & Erythematous plaque & . & Phialophora verrucosa & $\begin{array}{l}\text { AMP-B iv, } \\
\text { 5-flucytosine }\end{array}$ \\
\hline $\begin{array}{l}\text { Present case } \\
(2010)\end{array}$ & $M / 39$ & 1 year & Lt. shin & Erythematous Plaque & $\cdot$ & Fonsecaea pedrosoi & $\mathrm{ICZ}$ \\
\hline
\end{tabular}

M: male, F: female, AMP-B: amphotericin B, ICZ: itraconazole, TBF: terbinafine. 
with slightly elevated center. According to the microscopic examination, the spores were oval in shape and displayed the Cladosporium type sporulation. Recently, De Hoog et al. $^{20}$ performed the base sequence and phylongenetic analysis of ITS from the nucleus of Fonsecaea, and were able to separately identify and name F. monophora, apart from F. pedrosoi. Subsequently, they classified them into group A, B and C. In 2007, Yaguchi et al. ${ }^{7}$ performed further base sequence and phylogenetic analysis and were able to identify $F$. pedrosoi. Thus, $F$. monophora, group A was divided into A1 and A2, and the B group into B1, B2 and B3, respectively. The A1 group was the strain from Thailand, Australia, South America and Africa. The A2 group was the strain from Central and South America. The B1 group was the strain from Central and South America and Africa, B2 was from Japan and China and the B3 group was the strain from the United States and United Kingdom. In this case study, DNA was extracted from the cultured colonies, and the base sequence of ITS was identified. Subsequently, using the Blast program, it was compared to the base sequence of the reported strain in Thailand (stored in GeneBank), i.e. F. pedrosoi IFM 47061 (GenBank accession number $\mathrm{AB} 240943)$. The result was $100 \%$ match, so it was clear that the strain in our patient was from group A1.

The patient in this case was a Thai worker living in Korea and the base sequence matched the reported $F$. pedrosoi IFM 47061. This was in accordance with the regional distribution findings of Yaguchi et al. ${ }^{7}$. With clinical, histopathological and mycological results, as well as molecular biological findings, we were able to diagnose the patient as having chromoblastomycosis by the strain $F$. pedrosoi.

The initial treatment consisted of excision, skin grafting and other treatments, such as localized hyperthermia and cryosurgery or administering itraconazole, 5-fluorocytosine, or amphotericin $\mathrm{B}^{1-3}$. Effective treatments usually try to prevent the localized recurrence by wide margin excision of small or localized lesion areas. However, as in our case, too extensively distributed lesions and deep infections were not suitable for excision. Thus, in our case, we could not perform surgical excision, because of extensive distribution of the lesions. The patient showed clinical improvement to 3 months oral administration of itraconazole.

\section{REFERENCES}

1. Queiroz-Telles F, Esterre P, Perez-Blanco M, Vitale RG, Salgado CG, Bonifaz A. Chromoblastomycosis: an overview of clinical manifestations, diagnosis and treatment. Med
Mycol 2009;47:3-15.

2. Kwon-Chung KJ, Bennett JE. Medical mycology. Philadelphia: Lea \& Febiger, 1992:337-355.

3. López Martínez R, Méndez Tovar LJ. Chromoblastomycosis. Clin Dermatol 2007;25:188-194.

4. Suh MK, Lee YH. Infectious caused by dematiaceous fungi. Korean J Med Mycol 2005;10:77-82.

5. Santos AL, Palmeira VF, Rozental S, Kneipp LF, Nimrichter L, Alviano DS, et al. Biology and pathogenesis of Fonsecaea pedrosoi, the major etiologic agent of chromoblastomycosis. FEMS Microbiol Rev 2007;31:570-591.

6. Kondo M, Hiruma M, Nishioka Y, Mayuzumi N, Mochida K, Ikeda S, et al. A case of chromomycosis caused by Fonsecaea pedrosoi and a review of reported cases of dematiaceous fungal infection in Japan. Mycoses 2005; 48:221-225.

7. Yaguchi T, Tanaka R, Nishimura K, Udagawa S. Molecular phylogenetics of strains morphologically identified as Fonsecaea pedrosoi from clinical specimens. Mycoses 2007; 50:255-260.

8. Ahn SK, Lee SN. A case of chromonycosis. Korean J Dermatol 1990;28:345-348.

9. Suh MK, Sung YO, Yoon KS, Ha GY, Kim JR. A case of chromoblastomycosis caused by Fonsecaea pedrosoi. Korean J Dermatol 1996;34:832-836.

10. Kim HU, Son GY, Ihm CW. A case of chromoblastomycosis showing a good response to itraconazole. Ann Dermatol 1997;9:51-54.

11. Kim SW, Oh SH, Choi SK, Lee YH, Yoon JH, Bang YJ, et al. Chromoblastomycosis treated with occlusive dressing of amphotericin B cream. Korean J Med Mycol 2000;5: 144-149.

12. Kang NG, Suh MK, Park SG, Song KY, Kim TH. A case of chromomycosis showing ulcerative lesions on dorsa of hands. Korean J Dermatol 2002;40:174-177.

13. Lee $\mathrm{CW}$, Sim SJ, Song $\mathrm{KH}$, Kim KH. A case of chromoblastomycosis treated with terbinafine. Korean J Med Mycol 2003;8:26-29.

14. Jun JB, Park JY, Kim DW, Suh SB. Chromoblastomycosis caused by Rhinocladiella aquaspersa. Korean J Med Mycol 2004;9:117-122.

15. Park SG, Oh SH, Suh SB, Lee KH, Chung KY. A case of chromoblastomycosis with an unusual clinical manifestation caused by Phialophora verrucosa on an unexposed area: treatment with a combination of amphotericin $\mathrm{B}$ and 5-flucytosine. Br J Dermatol 2005;152:560-564.

16. De Hoog GS, Queiroz-Telles F, Haase G, FernandezZeppenfeldt G, Attili Angelis D, Gerrits Van Den Ende AH, et al. Black fungi: clinical and pathogenic approaches. Med Mycol 2000;38 Suppl 1:243-250.

17. Minotto R, Bernardi CD, Mallmann LF, Edelweiss MI, Scroferneker ML. Chromoblastomycosis: a review of 100 cases in the state of Rio Grande do Sul, Brazil. J Am Acad Dermatol 2001;44:585-592.

18. Silva JP, de Souza W, Rozental S. Chromoblastomycosis: a retrospective study of 325 cases on Amazonic region (Brazil). Mycopathologia 1998-1999;143:171-175. 
19. Hinshaw $M$, Longley $B J$. Fungal diseases. In: Elder DE, Elenitsas R, Johnson BL, Murphy GF, editors. Lever's histopathology of the skin. 9th ed. Philadelphia: Lippincott Williams \& Wilkins, 2005:619-620.
20. De Hoog GS, Attili-Angelis D, Vicente VA, Van Den Ende $\mathrm{AH}$, Queiroz-Telles F. Molecular ecology and pathogenic potential of Fonsecaea species. Med Mycol 2004;42: 405-416. 